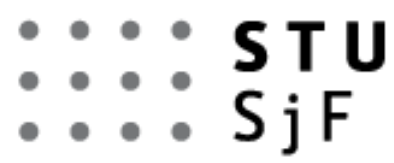

DE GRUYTER OPEN

\title{
EXPERIMENTAL EVALUATION OF MECHANICAL PROPERTIES OF FRICTION WELDED DISSIMILAR STEELS UNDER VARYING AXIAL PRESSURES
}

\author{
Amit Handa ${ }^{1}$, Vikas Chawla ${ }^{2}$ \\ ${ }^{I}$ Professor, Department of Mechanical Engineering, RIMT University, Mandi Gobindgarh (Punjab) \\ India., e-mail: handaamit_2002@yahoo.com \\ ${ }^{2}$ Professor, Department of Mechanical Engineering, Ferozepur College of Engineering and Technology, \\ Ferozshah (Punjab) India.
}

\begin{abstract}
The present study emphasizes on joints two industrially important materials AISI 304 with AISI 1021 steels, produced by friction welding have been investigated. Samples were welded under different axial pressures ranging from $75 \mathrm{MPa}$ to $135 \mathrm{MPa}$, at constant speed of $920 \mathrm{rpm}$. The tensile strength, torsional strength, impact strength and micro hardness values of the weldments were determined and evaluated. Simultaneously the fractrography of the tensile tested specimens were carried out, so as to understand the failure analysis. It was observed that improved mechanical properties were noticed at higher axial pressures. Ductile failures of weldments were also observed at $120 \mathrm{MPa}$ and $135 \mathrm{MPa}$ axial pressures during fractography analysis.
\end{abstract}

KEYWORDS: Friction Welding; Tensile Strength; Torsion Strength; Impact Strength; Micro Hardness; Scanning Electron Microscopy.

\section{Introduction}

Dissimilar joints between austenitic stainless steel and low alloy steel are extensively used in many high temperature applications in the energy conversion system (Handa \& Chawla, 2013 a). There is an extensive need for dissimilar metal joints in power plant components, due to the severe gradients in mechanical and thermal loading. In central power stations, the parts of the boiler that are subjected to lower temperatures, are made of low alloy steel for economic reasons. The other parts, operating at higher temperatures, are constructed with austenitic stainless steel. Therefore, transition welds are needed between these two materials. The joining of dissimilar materials is generally more challenging than those of the similar materials due to difference in thermal, metallurgical and physical properties of the parent materials. The specific problems associated with welding of austenitic stainless steel are formation of delta ferrite, sigma phase, stress corrosion cracking, and sensitization at the interface. Friction welding is one such solid state welding process widely employed in such situations (Meshram et al 2008, Sathiya et al 2007). Main advantages of friction welding are high material saving, low production cost, and ability to weld dissimilar materials (Sahin, 2004). Friction welding is one of the versatile and well established welding processes (Meshram et al 2008) that are capable of giving good quality welds; it gives solid state joining of the materials through the controlled rubbing of the interfaces. Due to thus produced heat softens the material and brought the localized faces into the plasticized form which results in good quality welds (Sathiya et al, 2009). In this process heat energy is produced by the 
interconversion of mechanical energy into thermal energy (Kelemen \& Kelemenova, 2007) at the interfaces of the rubbing components.

\section{Materials and Methods}

Austenitic stainless steel AISI 304 and low alloy steel AISI 1021 specimens having diameter of $20 \mathrm{~mm}$ and $100 \mathrm{~mm}$ length were joined together. The chemical composition of austenitic stainless steel and low alloy steel is presented in Table 1. A continuous drive lathe machine was used for the experimentation. A designed load cell (Handa \& Chawla, 2013 b) was fitted on the machine to measure axial pressure. Test samples with $20 \mathrm{~mm}$ diameter and $100 \mathrm{~mm}$ length were prepared for friction welding experiments. Prior to friction welding the contacting surfaces was faced on the lathe machine and then cleaned using acetone (Sathiya et al, 2005).

Table 1 Chemical composition of the parent materials

\begin{tabular}{lllllllll}
\hline Metal & Cr & Ni & C & Mn & Si & P & S & Fe \\
\hline AISI 304 & $17-20$ & $9-13$ & 0.08 & 2 & 0.75 & ---- & ---- & Remaining \\
AISI 1021 & ---- & ---- & $0.15-$ & $0.6-$ & ---- & --- & --- & Remaining \\
& & & 0.25 & 0.9 & & & & \\
\hline
\end{tabular}

The rotational speed for this study selected was 920rpm. The required rotational speed was set by the levers attached on this machine. Within a fraction of seconds, the constant speed was achieved; subsequently the axial alignment of the specimens was checked. Then the axial pressure was applied. The welds were prepared at different axial pressures in the steps of $15 \mathrm{MPa}$ starting from $75 \mathrm{MPa}$ to $135 \mathrm{MPa}$ to form different welds for the study. The welding joint so formed was allowed to cool down for 4-5 minutes. In this way, necessary number of weldments were prepared and subjected to various tests for evaluation of their mechanical characterization. Figure 1 shows the welded specimens at different axial pressures.

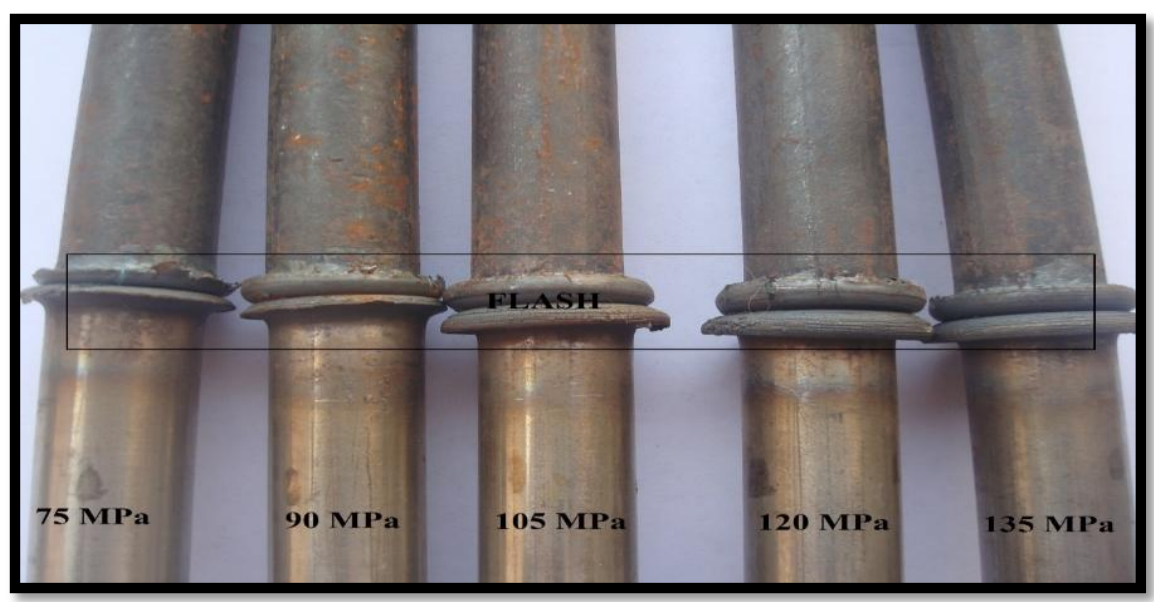

Fig. 1 Friction weldments produced at various axial pressures

\section{Results and Discussion}

Friction welded parts were subjected to variety of mechanical tests to determine their suitability for the anticipated service applications. They were necessary to carry out so as to ensure the quality, reliability and strength of the welded joints. In our investigation mechanical properties like tensile strength, impact strength and micro hardness were evaluated combined with the visual examination. 


\subsection{Visual Examination}

The friction welded specimens of five different welding combinations were prepared by varying the axial pressures at constant speed of 920rpm; it was observed that the flash has been produced during friction welding process and the amount of flash increases with the increase in axial pressure. The formation of flash has been reported in Fig. 1. The experimental observations made during friction welded shows that the formation of flash is higher towards the low alloy steel than that of austenitic stainless steel for all the cases. This might be attributed to the presence of $\mathrm{Cr}$ in austenitic stainless steel, also austenitic stainless steel having greater hardness at higher temperatures as compared to low alloy steels. For this reason austenitic stainless steel does not undergo extensive deformation while the low alloy steel undergoes extensive deformation. This phenomenon may be attributed to the low strength of AISI 1021 steel (Satyanarayana et al, 2005).

\subsection{Tensile Testing}

Tensile test was performed on the Universal Testing Machine of make HIECO, having the capacity $600 \mathrm{KN}$. The standard specimens using ASTM standards were followed for preparing the samples. The gauge lengths of the specimens were maintained according to the ASTM A370-12 standards keeping the weld interface at the center of the gauge length. This test was carried out on the samples to know their strength in tension, the specimens were subjected to axial tensile stress, and load was applied gradually till the fracture occurs. In all the cases, the strain increases with the rise in stress, subsequently, the stress starts declining after achieving a maximum value, however, the strain continuously increases till the fracture occurs; similar results have been reported by Ozdemir, 2005. Fig. 2 shows the variation of stress Vs strain at different axial pressures, it depicts that with the increase in stress the strain increases.

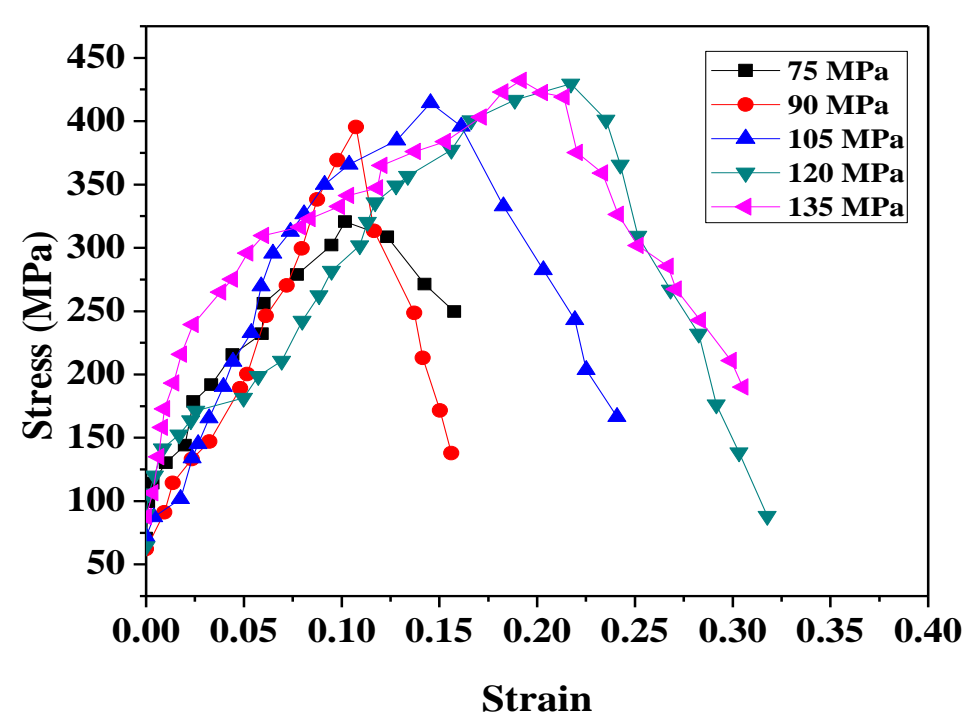

Fig. 2 Relationship of Stress Vs Strain at different axial pressures

It is evident from the figure that during tensile testing, brittle fracture appeared to occur at $75 \mathrm{MPa}$ and $90 \mathrm{MPa}$ axial pressures and the joint fails from the weld interface without showing any necking; whereas at an axial pressure of $105 \mathrm{MPa}$ the joint too failed from the weld interface but small amount of necking appears at the weld interfaces; whereas cup and cone fractures observed at pressures of 120 and $135 \mathrm{MPa}$. The tensile strength of these two specimens was found to be much more than the other samples. This might be attributed to the 
increase in the axial pressures, more mass is thought to be transferred out of the interface due to more friction, thus increasing the tensile strength. Tensile strength obtained from the specimens varied from $320.57 \mathrm{MPa}$ to $432.20 \mathrm{MPa}$.

Table 2 Maximum values of stress and strain at different axial pressures

\begin{tabular}{lllll}
\hline $\begin{array}{l}\text { Sample } \\
\text { No. }\end{array}$ & $\begin{array}{l}\text { Axial Pressure } \\
\text { (MPa) }\end{array}$ & $\begin{array}{l}\text { Max. Stress } \\
(\mathbf{M P a})\end{array}$ & $\begin{array}{l}\text { Max. } \\
\text { Strain }\end{array}$ & Fracture Location \\
\hline S 1 & 75 & 320.57 & 0.1577 & At Weld Interface \\
S 2 & 90 & 395.32 & 0.1562 & At Weld Interface \\
S 3 & 105 & 414.33 & 0.2408 & At Weld Interface \\
S4 & 120 & 429.67 & 0.3178 & $\begin{array}{l}\text { Away from Weld } \\
\text { Interface }\end{array}$ \\
S 5 & 135 & 432.20 & 0.3052 & $\begin{array}{l}\text { Away from Weld } \\
\text { Interface }\end{array}$ \\
\hline
\end{tabular}

Table 2 shows the maximum values of stress and strain; similar results have been reported by Arivazhagan et al, 2011. The value of strain varied from 0.1562 to 0.3178 , depending upon the axial pressure used. It also depicts that the specimen welded at $120 \mathrm{MPa}$ shows the maximum ductile behavior while the maximum strength was achieved at an axial pressure of $135 \mathrm{MPa}$.

\subsection{SEM Analysis}

For supporting the visual inspection of failure, the fracture analysis was done. For that scanning electron microscope (SEM) of make JEOL model no. JSM-6610LV was used. The SEM analysis was carried out to show the fracture behavior of tensile test which justifies the visual inspection results of brittle and ductile failures. The magnified images were captured at the fractured locations taken at 1,500 X magnification. The effect of tensile strength has been observed on the fractured surface appearance. In the fig. 3 (A), the fractograph indicates the pure brittle failure. This might be owing to the transformation of austenite into martensite at the interface of the joints (Ozdemir and Orhan, 2005), also has been observed from the tensile test that minimum time has been taken by the specimen before getting failed.

Fig. 3 (B) indicates the sign of river like pattern, which depicts the brittleness of the joint. Fig. 3 (C) reveals cleavage pattern as well as dimples at various locations; this indicates the fracture may have occurred by the mixed phenomenon i.e. quasi cleavage fracture mechanism (Chawla et al, 2008). Fig. 3 (D) and (E) represents dimpled pattern showing ductile fracture. Fig 3 (D) and (E) also depicts that the dimples are deep as compared to fig. 3 (C) indicating more ductility. In the fig. (D) and (E) the failure was located in AISI 1021 side therefore ductile fracture similar to that of pure Fe was observed (Meshram et al, 2008).

\subsection{Torsion Test Analysis}

Torsion test was performed on the torsion testing machine of make scientific instruments limited. In this test torque was applied on the specimens till its fracture occurs. The specimen was fitted in the jaws of machine with one jaw is kept fixed and other rotates when the torque is applied. During the application of twisting moment the specimen a start twisting at an angle called angle of twist and this angle was measured during the application of torque. The maximum torsion strength obtained from the tests varied from $12.72 \mathrm{Nm}$ to $21.35 \mathrm{Nm}$ and the angle of twist in terms of degrees varied from $8^{\circ}$ to $16^{\circ}$, Similar results have been reported by 
Shribman at el 2002 and Shribman 2008. It has also been observed during testing that the entire specimen fails at the weld interfaces. Fig. 4 shows the variation of the torque with respect to angle of twist. With the increase in torque the angle of twist increases; it has also been noticed from the experiment that with the increase in axial pressure the torque as well as the angle of twist increases.

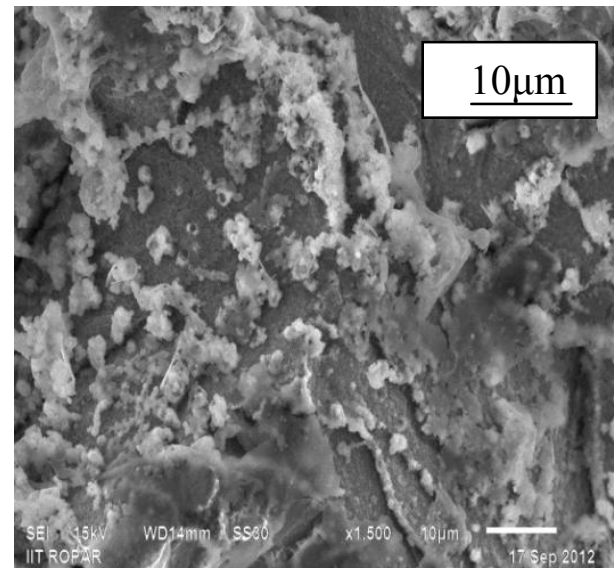

(A) SEM image at $75 \mathrm{MPa}$ axial pressure

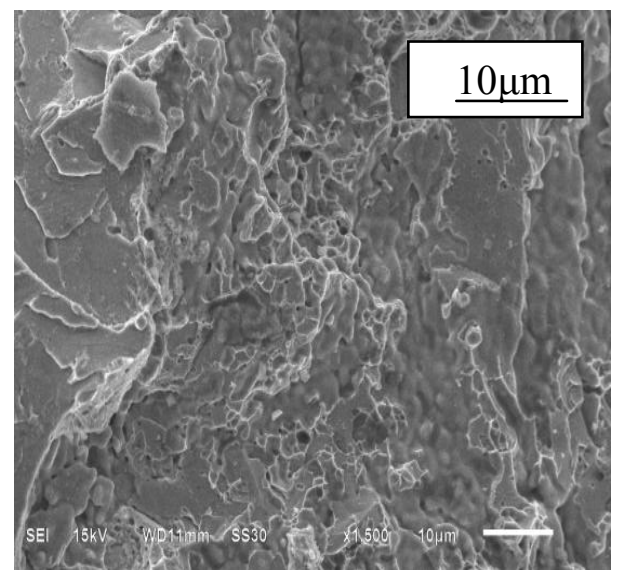

(c) SEM image at $105 \mathrm{MPa}$ axial pressure

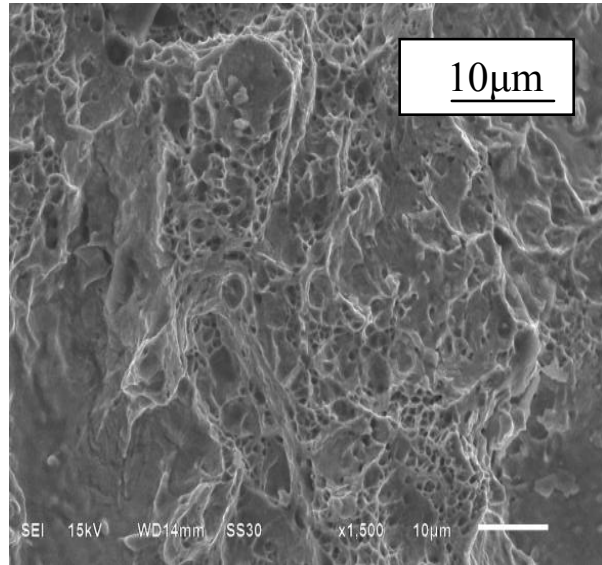

(B) SEM image at $90 \mathrm{MPa}$ axial Pressure

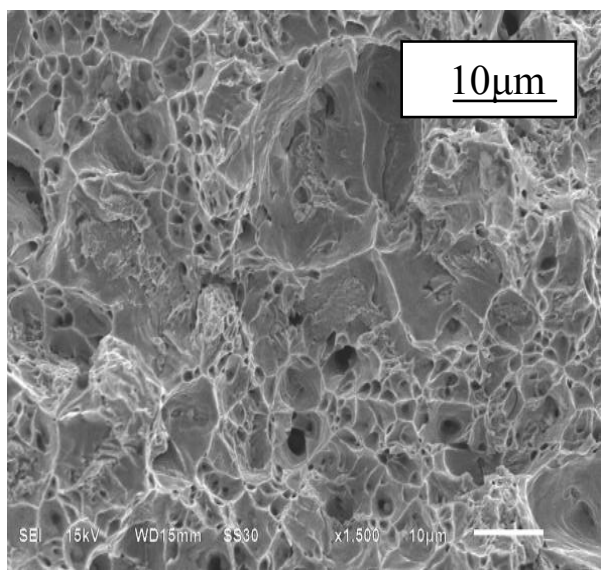

(D) SEM image at $120 \mathrm{MPa}$ axial Pressure

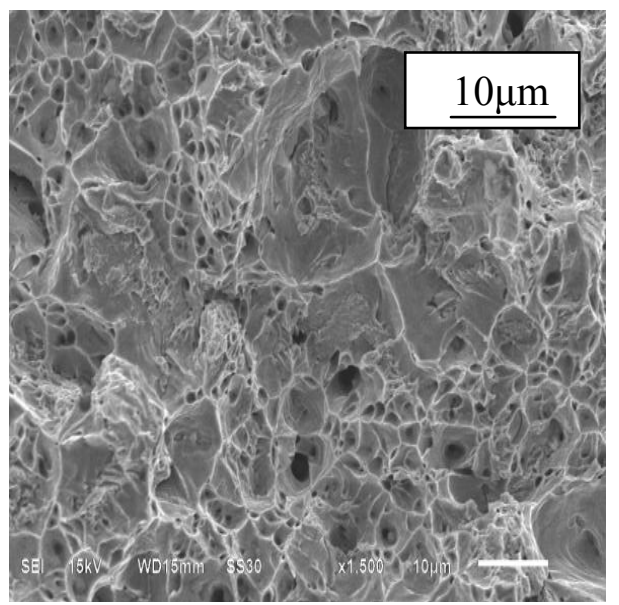

(E) SEM image at $135 \mathrm{MPa}$ axial pressure

Fig. 3 SEM fractograph of friction welded AISI 304 and AISI 1021 steel samples failed under tensile testing produced at $920 \mathrm{rpm}$ and at several axial pressures. 
This might be the effect of the diffusion of alloying elements from austenitic stainless steel to low alloy steel at the joint interface (Handa \& Chawla, 2014 a). When the axial pressure increases beyond $120 \mathrm{MPa}$ there is little bit decline in the torque but this difference is very marginal. The maximum torque available was $21.35 \mathrm{Nm}$ and the maximum angle of twist was $16^{\circ}$ and these results were obtained at $120 \mathrm{MPa}$ axial pressure. The torsion test values have been reported in Table 3 .

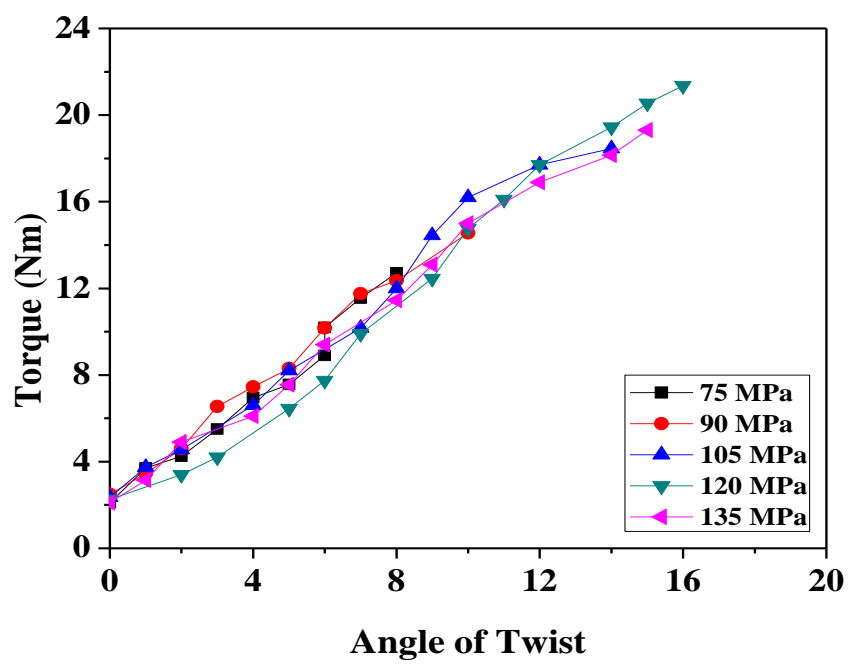

Fig. 4 Relationship between Torque and Angle of Twist

Table 3 Torsional values at different axial pressures

\begin{tabular}{lllll}
\hline $\begin{array}{l}\text { Sample } \\
\text { No. }\end{array}$ & $\begin{array}{l}\text { Axial Pressure } \\
\text { (MPa) }\end{array}$ & $\begin{array}{l}\text { Max. Torque } \\
(\mathbf{N m})\end{array}$ & $\begin{array}{l}\text { Max. Angle of } \\
\text { Twist }\end{array}$ & $\begin{array}{l}\text { Fracture } \\
\text { Location }\end{array}$ \\
\hline S 1 & 75 & 12.72 & 8 & Weld Interface \\
S 2 & 90 & 14.53 & 10 & Weld Interface \\
S 3 & 105 & 18.41 & 14 & Weld Interface \\
S4 & 120 & 21.35 & 16 & Weld Interface \\
S 5 & 135 & 19.3 & 15 & Weld Interface \\
\hline
\end{tabular}

\subsection{Impact Test Analysis}

This test was carried out on the pendulum type single blow impact testing machine so as to measure their notch impact toughness. Again the samples were prepared according to the ASTM standards maintaining the notch at the center of the weld interface. For Charpy impact test the specimens were supported at both ends as a simple supported beam and was broken by a falling pendulum on the face opposite to the notch and the energy absorbed by the specimen was noted down. Side by side Izod test was also performed in this test the specimens were vertically placed and the notch was facing towards the falling pendulum. The notch impact toughness tests were carried out to find amount of energy absorbed during fracture. For this Charpy and Izod Impact tests were carried out so as to find out the amount of energy absorbed by the specimens before failure. The results of both Charpy and Izod impact test results in terms of energies absorbed before fracture have been reported in the Table 4. As it can be seen from the table that the Charpy toughness of the welded parts is slightly larger than the Izod impact toughness (Handa \& Chawla, 2014 a), this may be the reason of the placement of the impact samples towards the impact load.In case of Charpy Impact test, the specimens are placed as a simply supported and the blow of the hammer was done on the opposite side of the notch, while, in case of Izod Impact test, the specimens are 
placed as a cantilever and the notch of the specimen is facing towards the blow of impact. Fig. 5 reveals that the Charpy impact strength decreases with the increase in axial pressure. Almost similar trends have been recorded during Izod impact testing, Fig. shows that impact strength decreases a little bit at $105 \mathrm{MPa}$ and then it remains constant up to $135 \mathrm{MPa}$. The similar results have been reported in the literature (Sahin et al, 2007).

Table 4 Impact Strength at different axial pressures

\begin{tabular}{llll}
\hline Sample No. & Axial Pressure (MPa) & Charpy Impact (J) & Izod Impact (J) \\
\hline S 1 & 75 & 25 & 20 \\
S 2 & 90 & 25 & 20 \\
S 3 & 105 & 24 & 19 \\
S4 & 120 & 23 & 19 \\
S 5 & 135 & 21 & 19 \\
\hline
\end{tabular}

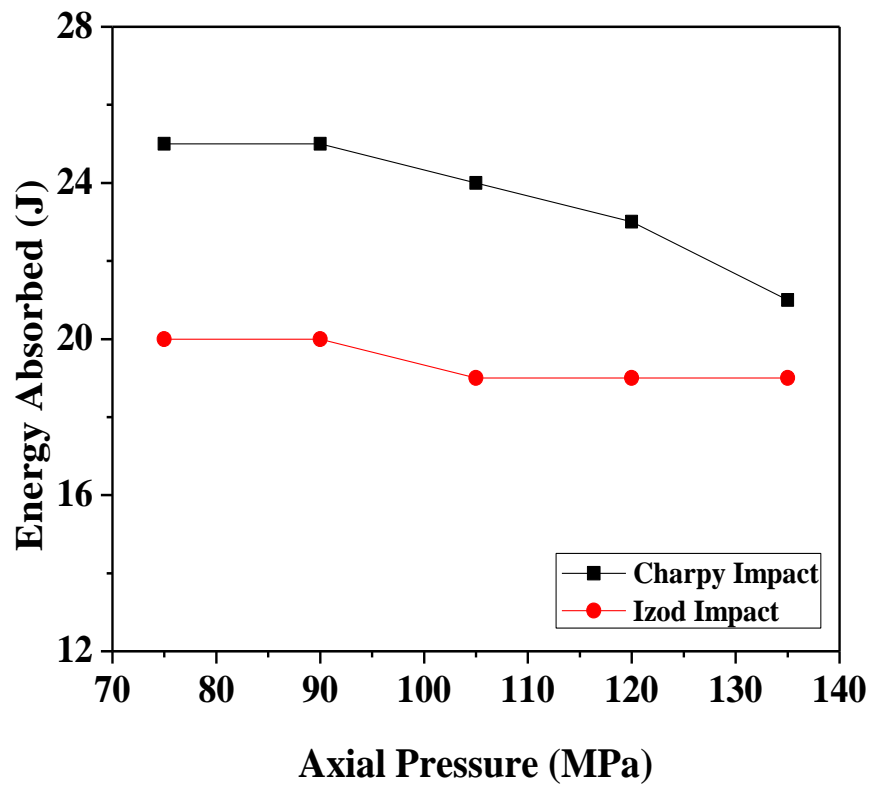

Fig. 5 Represents Impact Toughness at different axial pressures.

It has also been observed that with the increase in the axial pressure the flash increases, and experimentally it has been found that with the increase in the flash the impact strength decreases (Arivazhagan et al 2011, Arivazhagan et al 2008).

\subsection{Micro hardness Testing}

For micro hardness testing Vickers hardness testing machine was used (Singh et al, 2005). In this test a square based pyramid type diamond indenter was used and the hardness variation on the weld interface as well as along the axis of shaft at the intervals of $1 \mathrm{~mm}$ on both the parent materials was obtained by applying a constant load of 500gf. The indentations were made at the weld interface and on both the so as to find out the effect of heat on the hardness values. Fig. 6 shows the hardness variations on both the sides of the friction welded joint. Fig. 6 depicts that AISI 1021 showed less hardness as compared to that of AISI 304. This decreased hardness might be attributed to recrystallization process taking place at the heat affected zone towards the low alloy steel (Ananthpadmanadan et al 2009, Handa \& Chawla 2014b). It has also been observed that the maximum hardness was obtained at the weldinterface for all the joints (Handa \& Chawla 2014c, Ozdemir \& Orhan 2005). The peak 
hardness of friction welded joints increases with the increase in burn-off length (Arivazhagan et al, 2011), similarly our plot follows the identical trends. It was observed that with the increase in burn-off length a soft region appears on the austenitic stainless steel adjacent to the weld interface. The formation of soft region can be attributed to decarburization. This may be occurred by the presence of heat as the thermal conductivity of the material is relatively low (Satyanarayana et al, 2005).

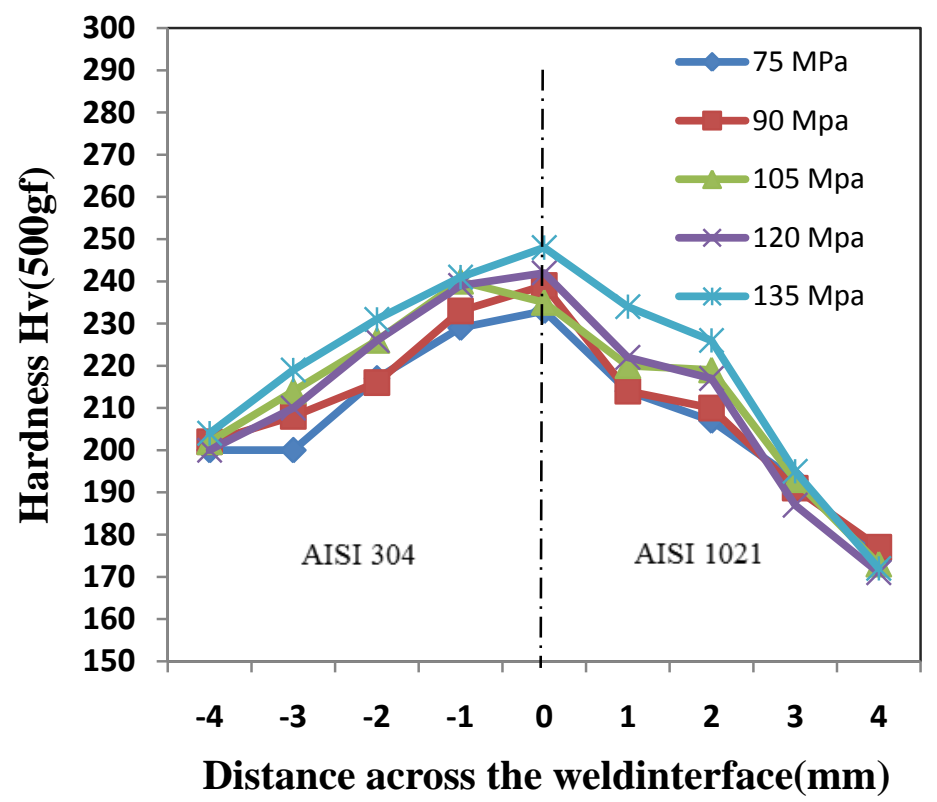

Fig 6 Hardness variations across the weld interface.

In addition to that the higher values of hardness at the weldinterface were probably due to the oxidation process which takes place during friction welding (Arivazhagan et al, 2011).

\section{CONCLUSION}

The axial pressure has been found to be an important parameter which determines the strength of the weldments. The mechanical properties of the weldments were found to vary with the variation in axial pressures during experimentation. The maximum tensile strength of $432 \mathrm{MPa}$ was attained at $135 \mathrm{MPa}$ axial pressure. This was due to the transfusion of alloying elements from the AISI 304 towards low alloy steel side. This might be attributed that at higher temperatures, more elemental diffusion takes place from the austenitic stainless steel towards the low alloy steel, thus increasing the bond strength. The increased friction pressure contributes to an increased friction time, which aids in raising the temperature in the vicinity of the interface and resulting in the increase of elemental migration. The ductility slightly decreases at $135 \mathrm{MPa}$ axial pressure. This reduction is probably due to flashing of the heated soft material from the interface on upset pressure. Fractography analysis revealed that ductile failures were observed at higher axial pressures. The torsional strength also increases with the rise in axial pressure. This was due to more transfer of the mass at higher axial pressures.

It has been observed that impact toughness of the weldments follows the reverse trend, it declines as axial pressure increases. The maximum impact toughness values of $25 \mathrm{~J}$ and $20 \mathrm{~J}$ both for Charpy and Izod were available at $75 \mathrm{MPa}$. With the increase in axial pressure, the hardness at the center of weld cross-section increases and maximum hardness was observed at $135 \mathrm{MPa}$. 


\section{Acknowledgements}

The authors would like to thank Professor Deepinder Singh, Head, Department of Mechanical Engineering RIMT-Institute of Engineering and Technology, Mandi Gobindgarh, for his continuous encouragement and timely support for revising this manuscript.

\section{REFERENCES}

[1] ANANTHAPADMANADAN, D., RAO, V. S., ABRAHAM, N, RAO, K. P.: (2009),“ A study of mechanical properties of friction welded mild steel to stainless steel joints", Materials and Design, Vol, 30, 2009, pp. 2642-2646.

[2] ARIVAZHAGAN, N., SINGH, S., PRAKASH, S., REDDY, G. M.: (2008) “An assessment of hardness, impact strength and hot corrosion behavior of friction-welded dissimilar weldments between AISI 4140 and AISI 304", International Journal of Advanced Manufacturing Technology, Vol. 39, 2008, pp. 679-689.

[3] ARIVAZHAGAN, N., SINGH, S., PRAKASH, S., REDDY, G. M.: (2011), "Investigation of AISI 304 austenitic stainless steel to AISI 4140 low alloy steel dissimilar joints by gas tungsten arc, electron beam and friction welding", Materials and Design, Vol. 32, 2011, pp. 3036-3050.

[4] CHAWLA, V., BATRA, U., PURI, D., CHAWLA, A.: (2008), "To study the effect of austempering temperature on fracture behavior of Ni-Mo austempered ductile iron", Journal of Minerals \& Materials Characterization \& Engineering, Vol. 7, 2008, pp. 307-316.

[5] HANDA, A., CHAWLA, V.: (2013a), "Mechanical characterization of friction welded dissimilar steels at 1000 rpm”, Mater. Eng.-Mater. Inz, Vol. 20, 2013, pp. 102-111.

[6] HANDA, A., CHAWLA, V.: (2013b), "Experimental study of mechanical properties of friction welded AISI 1021 steels", Sadhana - Academy Proceedings in Engineering Sciences., Vol. 38, 2013, pp. 1407-1419.

[7] HANDA, A., CHAWLA, V.: (2014), "Influence of process parameters on torsional strength, impact toughness and hardness of dissimilar AISI 304 and AISI 1021 friction welded steels", Mater. Eng.-Mater. Inz, Vol. 21, 2014, pp. 94-103.

[8] HANDA, A., CHAWLA, V.: (2014a), "Experimental evaluation of mechanical properties of friction welded dissimilar steels", Cogent Engineering, Vol. 1, 2014, pp. $1-10$.

[9] HANDA, A., CHAWLA, V.: (2014b), "An investigation on the effect of axial pressures on the mechanical properties of friction welded dissimilar steels", Advances in Mechanical Engineering, Vol. 2014, 2014, pp. 1-6.

[10] HANDA, A., CHAWLA, V.: (2014c), "Investigation of mechanical properties of friction welded AISI 304 with AISI 1021dissimilar steels", International Journal of Advanced Manufacturing Technology, Vol. 75, 2014, pp. 1493-1500.

[11] KELEMEN M, KELEMENOVA T.: (2007), "Identification of friction forces in the inpipe micromachine”, Strojnicky casopis - Journal of Mechanical Engineering, Vol. 58, 2007, pp. 71-84.

[12] MESHRAM, S.D., MOHANDAS, T., REDDY, G.M.: (2008), "Friction welding of dissimilar pure metals", Journal of Material Processing Technology, Vol. 184, 2008, pp. 330-337. 
[13] OZDEMIR, N.: (2005), "Investigation of the mechanical properties of friction welded joints between AISI 304L and 4340 steel as a function rotational speed", Materials Letters, Vol. 59, 2005, pp. 2504-2509.

[14] OZDEMIR, N., ORHAN, N.: (2005), "Microstructure and mechanical properties of friction welded joints of a fine-grained hypereutectoid steel with 4\% Al", Journal of Materials Processing Technology, Vol. 166, 2005, pp. 63-70.

[15] SAHIN, M.: (2004), "Simulation of friction welding using a developed computer program", Journal of Material Processing and Technology, Vol. 153, 2004, pp. 10111018.

[16] SAHIN, M., AKATA, H.E., GULMEZ, T.: (2007), “Characterization of mechanical properties in AISI 1040 parts welded by friction welding", Materials characterization, Vol. 58, 2007, pp. 1033-1038.

[17] SAHIN, M., AKATA, H.E., GULMEZ, T.: (2007), "Characterization of mechanical properties in AISI 1040 parts welded by friction welding", Materials characterization, Vol. 58, 2007, pp. 1033-1038.

[18] SATHIYA, P., ARAVINDAN, S., HAQ, A.N.: (2005), "Mechanical and metallurgical properties of friction welded AISI 304 austenitic stainless steel", International Journal of Advanced Manufacturing Technology, Vol. 26, 2005, pp. 505-511.

[19] SATHIYA, P., ARAVINDAN, S., HAQ, A.N., PANEERSELVAM, K.: (2009), "Optimization of friction welding parameter using evolutionary computational techniques", Journal of Materials Processing Technology, Vol. 209, 2009, pp. 25762584.

[20] SATHIYA, P., ARAVINDAN, S., HAQ, N.A.: (2007), "Some experimental investigations on friction welded stainless steel joints", Material and Design, Vol. 153, 2007, pp. 1099-1109.

[21] SATYANARAYANA, V. V., REDDY, G. M., MOHANDAS, T.: (2005), "Dissimilar metal friction welding of austenitic-ferritic stainless steel", Journal of Materials Processing Technology, Vol. 160, 2005, pp. 128-137.

[22] SHRIBMAN, V, STERN, A, LIVSHITZ, Y., GAFRI, O.: Magnetic pulse welding produces high strength aluminium welds. AWS Welding Journal, April 2002.

[23] SHRIBMAN, V.: Magnetic pulse welding for dissimilar and similar materials: 3rd international conference on high speed forming 2008: 13-22.

[24] SINGH S, MAHESHWARI S, DEY A, PANDEY P.C.: (2005), "Experimental investigations into die-sinking electric discharge machining of hardened AISI tool steel using different electrode materials", Strojnícky časopis - Journal of Mechanical Engineering, Vol. 56, 2005, pp. 197-210. 